\title{
Pengaruh Level Pemberian Bokashi Cair Berbahan Dasar Limbah Biogas (Slurry) dan Ekstrak (Chromolaena odorata) terhadap Pertumbuhan Awal Lamtoro (Leucaena leucocephala)
}

Bruno Sengkoen $^{\mathrm{a}}$

${ }^{a}$ Fakultas Pertanian, Universitas Timor, Kefamenanu, TTU - NTT, Indonesia, email: brunosengkoen32@gmail.com

\section{Article Info}

\section{Article history:}

Received 22 Desember 2019

Received in revised form 15 Januari 2019

Accepted 22 Januari 2019

DOI:

https://doi.org/10.32938/ja.v3i1.479

\section{Keywords:}

Bokashi cair, Lamtoro, Slurry, Pertumbuhan

\begin{abstract}
Abstrak
Penelitian ini bertujuan untuk mengetahui pengaruh bokashi cair berbahan dasar limbah Biogas (Slurry) dan ekstrak (Chromolaena odorata) terhadap tingkat pertumbuhan awal lamtoro (Leucaena leuccephala). Penelitian menggunakan rancangan acak lengkap (RAL) yaitu dengan 4 perlakuan dan yang diulang sebanyak 4 kali sehingga di dapat 64 ulangan. Adapun perlakuan yang diberikan adalah R0 = Tanpa pemberian bokashi cair, R1 = Pemberian bokashi cair dengan dosis $50 \mathrm{ml} / 1$ liter air, R2 = Pemberian bokashi cair dengan dosis $150 \mathrm{ml} / 1$ liter air, R3 = Pemberian bokashi cair dengan dosis $250 \mathrm{ml} / 1$ liter air. Variabel yang diamati adalah tinggi tanaman, diameter batang, jumlah tangkai daun, bobot segar tanaman, dan bobot kering. Dari hasil analisis dan pembahasan yang dilakukan maka dapa disimpulkan bahwa pemberian bokashi dengan level ( $250 \mathrm{ml} / 1$ liter air) memberikan tinggi tanaman tertinggi, diameter batang terbesar, jumlah tangkai daun terbanyak, berat segar tanaman terberat dan berat kering tanaman terberat.
\end{abstract}

\section{Pendahuluan}

Pengembangan Hijauan Makanan Ternak (HMT) terutama tanaman lamtoro (Leucaena leucocephala) pada daerah tropis memiliki tantangan tersendiri mengingat pada umumnya daerah tropis memiliki kondisi curah hujan rendah, kelembaban rendah, intensitas cahaya dan evapotranspirasi yang sangat tinggi, sehingga tidak sedikit masalah yang ada terutama tentang kemampuan adaptasi dan toleransi tanaman di daerah tropis.

Salah satu hal yang dapat dilakukan untuk meningkatkan pertumbuhan dan produksi tanaman lamtoro (Leucaena leucocephala) adalah dengan pemberian pupuk. Pupuk adalah bahan yang diberikan ke dalam tanah baik yang organik maupun anorganik dengan maksud untuk mengganti kehilangan unsur hara dari dalam tanah dan bertujuan untuk meningkatkan produksi tanaman (Sutedjo, 2002). Salah satu jenis pupuk organik yang sekarang banyak digunakan adalah pupuk bokashi yang dibuat dengan memfermentasikan bahan-bahan organik seperti kotoran ternak, limbah industri, pupuk hijau dengan menggunakan starter EM4 (effective microorganisms 4) (Indriani, 2004).

Pupuk bokashi merupakan salah satu alternatif dalam penerapan teknologi pertanian organik yang berwawasan lingkungan dan berkelanjutan. Kotoran sapi adalah salah satu bahan organik yang mempunyai prospek yang baik untuk dijadikan pupuk organik, karena mempunyai kandungan unsur hara yang cukup tinggi yaitu $\mathrm{C}$ organik $18,76 \%, \mathrm{~N} 1,06 \%, \mathrm{P} 0,52 \%, \mathrm{~K} 0,95 \%$, Ca 1,06\%, Mg 0,86\%, Na 0,17\%, Fe 5726 ppm, Mn 334 ppm, Zn 122 ppm, Cu 20 ppm, Cr 6 ppm, C/N 16,90, Kadar air 24,21\% (Yulipriyanto, 2010). Proses pembuatan bokashi terutama dalam bentuk cair dapat dilakukan dengan memanfaatkan hasil buangan limbah biogas yang biasanya disebut slurry, yang merupakan salah satu limbah hasil proses fermentasi anaerob pada instalasi biogas. Slurry mengandung lebih sedikit bakteri patogen sehingga aman untuk digunakan sebagai pupuk (Prariesta dan Winata, 2009). Slurry dapat ditingkatkan nilai ekonomisnya dengan diolah menjadi pupuk organik cair. Menurut Oman (2003), sludge yang berasal dari biogas (slurry) sangat baik untuk dijadikan pupuk karena mengandung berbagai macam unsur yang dibutuhkan oleh tumbuhan seperti $\mathrm{P}$, $\mathrm{Mg}, \mathrm{Ca}, \mathrm{K}, \mathrm{Cu}$ dan $\mathrm{Zn}$. Kandungan unsur hara dalam limbah (slurry) hasil pembuatan biogas terbilang lengkap meskipun jumlahnya sedikit. Febriyanti et al. (2012) menambahkan bahwa pupuk limbah biogas mempunyai manfaat yang sama dengan pupuk kandang yaitu untuk memperbaiki struktur tanah dan memberikan unsur hara yang diperlukan tanaman. Bahkan, unsur-unsur tertentu seperti protein, selulosa, lignin, dan lain-lain tidak bisa digantikan oleh pupuk kimia.

Namun, untuk melengkapi kandungan unsur hara pada slurry perlu juga ditambahkan bahan lain yang sekiranya menunjang kandungan slurry tersebut. Salah satu yang dapat ditambahkan adalah dengan menggunakan ekstrak Chromolaena odorata, selain sebagai gulma ternyata Chromolaena odorata mengandung hara yang dibutuhkan oleh tanaman seperti nitrogen $(\mathrm{N}) 2,45 \%$, fosfor (P) 0,26\% dan kalium (K) 5,40 \% (Kastono, 2005). Berdasarkan uraianuraian tersebut maka telah dilakukan penelitian dengan judul Pengaruh Level Pemberian Bokashi Cair Berbahan Dasar Limbah Biogas (Slurry) Ekstrak (Chromolaena odorata) Terhadap Pertumbuhan Awal Lamtoro (Leucaena leucocephala).

\section{Metode}

Penelitian ini dilaksanakan pada kebun percobaan Fakultas Pertanian Universitas Timor, Kelurahan Sasi, Kecamatan Kota Kefamenanu, Kabupaten Timor Tengah Utara selama bulan Desember 2017-Maret 2018. Alat-alat yang digunakan dalam penelitian ini adalah mistar, alat tulis, buku, jangka sorong, timbangan digital (O’haus), linggis, parang, ember, jergen ukuran 30 liter, dan oven. Bahan-bahan yang digunakan dalam penelitian ini antara lain benih lamtoro (Leucaena leucocephala), polibag dengan ukuran $30 \mathrm{~cm}$ x $20 \mathrm{~cm}$, tanah vertisol dan bokashi cair

Metode yang digunakan dalam penelitian ini adalah metode experiment menggunakan Rancangan Acak Lengkap (RAL) dengan 4 perlakuan yang diulang sebanyak 4 ulangan. Adapun perlakuan yang diberikan adalah sebagai berikut :
$\mathrm{R} 0=$ Tanpa pemberian bokashi cair

$\mathrm{R} 1$ = Pemberian bokashi cair dengan dosis $50 \mathrm{ml} / 1$ liter air

$\mathrm{R} 2=$ Pemberian bokashi cair dengan dosis $150 \mathrm{ml} / 1$ liter air

$\mathrm{R} 3=$ Pemberian bokashi cair dengan dosis $250 \mathrm{ml} / 1$ liter air

Tabel 1. Hasil Analisis Sampel Kimia Bokashi Cair dan Tanah

\begin{tabular}{ccccc}
\hline \multirow{2}{*}{ No. } & \multirow{2}{*}{ Sampel } & N Total & P Tersedia & K Tersedia \\
\cline { 3 - 5 } & \multirow{2}{*}{1} & $\%$ & $(\mathrm{ppm})$ & $(\mathrm{ppm})$ \\
\cline { 3 - 5 } & \multirow{2}{*}{ Bokashi cair } & 0,07 & 25,27 & 291,00 \\
\cline { 3 - 5 } & \multirow{2}{*}{ Tanah } & $\mathrm{R}$ & $\mathrm{T}$ & $\mathrm{T}$ \\
\cline { 3 - 5 } & & $\mathrm{R}$ & 11,11 & 213,00 \\
\hline
\end{tabular}

Ket: Hasil Analisis Laboratorium Ilmu Tanah, Fakultas Pertanian Universitas Udayana Denpasar

Prosedur Pelaksanaan Penelitian

1) Pembuatan bokashi cair

- Cara Pembuatan :

a. Limbah biogas (slurry) ditampung dan dimasukkan ke dalam wadah plastik dengan ukuran 30 liter.

b. Pembuatan ekstrak Chromolaena odorata yaitu dengan mengumpulkan daun Chromolaena odorata kemudian di blender setelah itu dimasukkan air bersih 2 liter kemudian disaring untuk didapatkan ekstraknya dan selanjutnya ekstrak Chromolaena odorata kemudian dimasukkan ke dalam wadah plastik dan daduk hingga merata.

c. Selanjutnya larutkan Gula pasir setelah itu dimasukkan ke dalam wadah plastik yang telah disiapkan.

d. Lalu dimasukkan Bakteri dekomposer (EM4)

e. Limbah biogas (slurry) didiamkan selama 14 hari dan diaduk setiap hari. Wadah plastik ditutup rapat.

f. Setelah 14 hari pupuk cair sudah jadi kemudian disaring dan dikemas dan siap untuk diaplikasikan.

- Pengisian tanah pada polibag: Polibag yang digunakan dalam penelitian ini adalah polibag yang berukuran $30 \mathrm{~cm} \times 20 \mathrm{~cm}$, dengan jumlah keseluruhan sebanyak 64 buah polibag sesuai dengan perlakuan, yang ditanami satu anakan tanaman lamtoro (Leucaena leucocephala) pada setiap polibag. Tanah yang digunakan pada pengisian polibag merupakan tanah yang berwarna hitam (vertisol), gembur dan tidak padat yang ditimbang seberat $4 \mathrm{~kg}$ per pot polibag. Pada perlakuan R0 tidak menggunakan dosis bokashi cair limbah biogas, sedangkan pada perlakuan R1, R2 dan R3 menggunakan dosis bokashi cair.

- Persemaian benih: Persemaian benih dilakukan dengan terlebih dahulu membuat lubang tanam pada media tanah terisi di dalam polibag. Setelah benih tumbuh $10 \mathrm{~cm}$ dipindahkan ke polibag perlakuan dan setiap perlakuan ditanam 2 anakan dengan kedalaman $3 \mathrm{~cm}$ selanjutnya ditutup dan dipadatkan.

- Penjarangan: Penjarangan dilaksanakan setelah 2 minggu Hari Setelah Tanam (HST) yaitu dengan cara pemotongan tanaman lain hingga menyisakan 1 tanaman/polibag. Penjarangan dilakukan pada pemotongan pangkal tanaman hingga rata dengan media tanam.

- Pemeliharaan tanaman, Penyiraman dilakukan dua kali sehari yaitu pagi dan sore hari dan penyiagaan dilakukan jika terdapat gulma yang tumbuh di polibag.

2) Perlakuan bokashi cair

a) Penyiraman anakan lamtoro pada polibag yang menggunakan perlakuan bokashi cair sesuai dengan dosis perlakuan.

b) Pemberian bokashi cair limbah biogas dilakukan setiap 2 hari sesuai dengan dosis perlakuan. 
Pengambilan data dalam penelitian ini sebanyak 4 kali, yaitu pada umur 14, 28, 42 dan 56 HST dan selanjutnya data tersebut dihitung nilai rataan semua pengukuran. Variabel penelitian yang diukur adalah tinggi anakan, diameter batang, jumlah tangkai daun, bobot segar tanaman dan bobot kering tanaman. Data dianalisis menggunakan sidik ragam (Anova) Rancangan acak Lengkap faktorial. Rata-rata perlakuan selanjutnya diuji lanjut dengan menggunakan Tukey HSD dengan signifikan 5\% sesuai petunjuk Gomez dan Gomez (2010). Analisis data menggunakan program SAS 9.1.

\section{Hasil dan Pembahasan}

\subsection{Tinggi Tanaman}

Tinggi tanaman adalah salah satu parameter yang digunakan untuk mengetahui respon pertumbuhan tanaman dengan perlakuan yang diberikan. Tabel 2 merupakan rataan tinggi tanaman lamtoro pada level pemberian dosis bokashi cair berbahan dasar slurry.

Tabel 2. Tinggi Tanaman (cm/56 hari).

\begin{tabular}{cccccc}
\hline \multirow{2}{*}{ Dosis bokashi cair } & \multicolumn{4}{c}{ Ulangan } & \multirow{2}{*}{ Rerata } \\
\cline { 2 - 5 } & I & II & III & IV & \\
\hline Kontrol & 24,33 & 31,62 & 32,03 & 25,40 & $28,34^{\mathrm{a}}$ \\
\hline $50 \mathrm{ml} / 1$ liter air & 31,53 & 31,43 & 29,27 & 23,76 & $29,00^{\mathrm{a}}$ \\
\hline 150ml/1 liter air & 28,29 & 28,46 & 31,04 & 26,01 & $28,45^{\mathrm{a}}$ \\
\hline $250 \mathrm{ml} / 1$ liter air & 30,79 & 31,78 & 34,31 & 30,38 & $31,82^{\mathrm{a}}$ \\
\hline
\end{tabular}

Ket: Angka yang diikuti superscript yang sama menunjukkan berbeda tidak nyata $(P>0,05)$ pada $\alpha 0,05$.

Hasil sidik ragam (anova) menunjukkan level bokashi cair tidak menunjukkan pengaruh nyata antar perlakuan terhadap variabel pengamatan tinggi tanaman. Rataan nilai pengukuran tinggi tanaman tertinggi adalah pada perlakuan $250 \mathrm{ml} / 1$ liter air $(31,82 \mathrm{~cm} / 56$ hari) kemudian diikuti oleh perlakuan $50 \mathrm{ml} / 1$ liter air $(29,00 \mathrm{~cm} / 56)$ hari dikuti lagi oleh perlakuan $150 \mathrm{ml} / 1$ liter air $(28,45 \mathrm{~cm} / 56$ hari) dan perlakuan kontrol $(28,34 \mathrm{~cm} / 56$ hari). Hal ini diduga karena adanya kandungan unsur $\mathrm{N}$ pada perlakuan $250 \mathrm{ml} / 1$ liter air $=52,5 \%$, unsur P perlakuan $250 \mathrm{ml} / 1$ liter air $=1,0 \%$, dan Unsur $\mathrm{K}$ perlakuan $250 \mathrm{ml} / 1$ liter air $=12,5 \%$ dapat memberikan hasil pertumbuhan per hari yang tertinggi pada tanaman perlakuan $(250 \mathrm{ml} / 1$ liter air : $0,57 \mathrm{~cm} / \mathrm{hari})$, urutan ke 2 dicapai oleh tanaman perlakuan $(50 \mathrm{ml} / 1$ liter air : $0,51 \mathrm{~cm} / \mathrm{hari})$ dan selanjutnya perlakuan $(150 \mathrm{ml} / 1$ liter air : 0,50 cm/hari), kemudian disusul oleh tanaman dan urutan terakhir adalah tanaman perlakuan (Kontrol : $0,50 \mathrm{~cm} / \mathrm{hari}$ ) dapat dijelaskan bahwa dengan kandungan unsur hara tersebut, memacu pertumbuhan tanaman lamtoro akan optimal yang dilihat dari tinggi tanaman. Jika dibandingkan dengan penelitian Marsela et al. (2017), menunjukkan bahwa tanaman lamtoro yang diberi perlakuan pupuk bokashi kotoran ayam dengan takaran 800 gram/pot memberikan hasil terbaik $0,48 \mathrm{~cm} /$ hari. Dalam penelitian ini sedikit lebih nyata yang diduga diakibatkan oleh kandungan unsur hara pupuk. Pupuk cair memiliki kandungan unsur hara tergolong tinggi (Tabel 1) yang didapat dari slurry, EM4 dan ekstrak Chromolaena odorata mampu meningkatkan pertumbuhan tanaman.

Penggunaan pupuk memiliki kandungan unsur hara yang ada dalam pupuk bokashi dapat memacu pertumbuhan tanaman seperti yang dinyatakan oleh Nasir (2008), penggunaan pupuk bokashi berpengaruh terhadap peningkatan ketersediaan nutrisi tanaman, aktivitas hama dan penyakit/patogen dapat ditekan, peningkatan aktivitas mikroorganisme indogenus yang menguntungkan, seperti mycorhiza, rhizobium, bakteri pelarut fosfat, fiksasi nitrogen, mengurangi kebutuhan pupuk dan pestisida kimia. Hal ini sejalan dengan pernyataan Hidayat (2003), bahwa pemupukan berkaitan erat dengan ketersediaan unsur hara esensial yang dibutuhkan oleh tanaman. Penggunaan pupuk dalam kegiatan budidaya dimaksudkan untuk meningkatkan ketersediaan hara dalam tanah bagi tanaman. Unsur hara esensial yang dibutuhkan oleh tanaman diantaranya nitrogen $(\mathrm{N})$, phospor $(\mathrm{P})$ dan kalium $(\mathrm{K})$. Peran utama nitrogen bagi tanaman adalah untuk merangsang pertumbuhan tanaman secara keseluruhan, khususnya batang, cabang dan daun. Nitrogen juga berperan penting dalam hal pembentukan hijau daun yang berguna sekali dalam fotosintesis (Lingga, 2003)

\subsection{Diameter Batang}

Diameter batang didefinisikan sebagai panjang garis antara dua buah titik pada lingkaran di sekeliling batang yang melalui titik pusat (sumbu) batang. Diameter batang diukur pada bagian bawah tanaman dengan menggunakan jangka sorong. Hasil pengamatan diameter batang ditujukan pada Tabel 3.

Tabel 3. Diameter Batang (cm/56 hari).

\begin{tabular}{|c|c|c|c|c|c|}
\hline \multirow{2}{*}{ Dosis bokashi cair } & \multicolumn{4}{|c|}{ Ulangan } & \multirow{2}{*}{ Rerata } \\
\hline & I & II & III & IV & \\
\hline Kontrol & 0,38 & 0,43 & 0,39 & 0,38 & $0,39^{\mathrm{b}}$ \\
\hline $50 \mathrm{ml} / 1$ liter air & 0,40 & 0,45 & 0,45 & 0,41 & $0,43^{\mathrm{ab}}$ \\
\hline $150 \mathrm{ml} / 1$ liter air & 0,43 & 0,47 & 0,43 & 0,44 & $0,44^{\mathrm{a}}$ \\
\hline $250 \mathrm{ml} / 1$ liter air & 0,43 & 0,48 & 0,45 & 0,47 & $0,46^{\mathrm{a}}$ \\
\hline
\end{tabular}

Ket: Angka yang diikuti superscript yang sama menunjukkan berbeda tidak nyata $(P>0,05)$ pada $\alpha 0,05$.

Hasil sidik ragam menunjukkan level bokashi cair menunjukkan beda nyata antar perlakuan terhadap variabel pengamatan diameter batang, dimana tanaman lamtoro yang diberikan bokashi cair $(250 \mathrm{ml} / 1$ liter air) cenderung meningkatkan diameter batang $(0,46 \mathrm{~cm})$ dibandingkan tanaman lamtoro yang diberikan bokashi cair 50ml/1 liter air, 150ml/1 liter air dan tanpa pemberian bokashi cair.

Rataan nilai pengukuran diameter batang tertinggi adalah pada perlakuan $250 \mathrm{ml} / 1$ liter air $(0,46 \mathrm{~cm} / 56$ hari) kemudian diikuti oleh perlakuan $150 \mathrm{ml} / 1$ liter air $(0,44 \mathrm{~cm} / 56$ hari $)$ dikuti lagi oleh perlakuan $50 \mathrm{ml} / 1$ liter air $(0,43 \mathrm{~cm} / 56$ hari) dan perlakuan kontrol $(0,39 \mathrm{~cm} / 56$ hari). Hal ini terjadi karena dengan tersedianya unsur hara kalium $(\mathrm{K})$ pada perlakuan $50 \mathrm{ml} / 1$ liter air $=2,5 \%, 150$ $\mathrm{ml} / 1$ liter air $=7,5 \%$ dan $250 \mathrm{ml} / 1$ liter air $=12,5 \%$, dapat memberikan hasil pertumbuhan per hari yang tertinggi pada tanaman perlakuan $250 \mathrm{ml} / 1$ liter air = $0,0082 \mathrm{~cm} /$ hari, kedua dicapai oleh tanaman perlakuan $150 \mathrm{ml} / 1$ liter air $=0,0078$ $\mathrm{cm} /$ hari, kemudian disusul oleh tanaman perlakuan $50 \mathrm{ml} / 1$ liter air $=0,0076$ $\mathrm{cm} /$ hari dan urutan terakhir adalah tanaman perlakuan kontrol $=0,0069 \mathrm{~cm} / \mathrm{hari}$. Dapat dijelaskan bahwa dengan kandungan unsur hara tersebut, memacu pertumbuhan tanaman lamtoro akan optimal yang dilihat dari diameter batang tanaman. Jika dibandingkan dengan dengan penelitian Nismawati (2013), menunjukkan bahwa tanaman semai kemiri yang diberi perlakuan pupuk bokashi dengan level tertinggi memberikan hasil terbaik $0,0065 \mathrm{~cm} /$ hari. Dalam penelitian ini sedikit lebih nyata yang diduga diakibatkan oleh kandungan unsur hara pupuk. Pupuk cair memiliki kandungan unsur hara tergolong tinggi yang didapat dari slurry, EM4 dan ekstrak Chromolaena odorata mampu meningkatkan pertumbuhan tanaman.

Semakin banyak tersedianya unsur kalium $(\mathrm{K})$ pada tanah dan bokashi cair dapat meningkatkan diameter batang tanaman semakin cepat bertambah panjang dan membesar. Ketersediaan hara $\mathrm{K}$ perlu dicermati karena adanya fenomena konsumsi "mewah" (luxury consumption), yakni tanaman menyerap K melebihi kebutuhan untuk pertumbuhan optimumnya (Tisdale et al., 1985). Pertumbuhan tanaman berkorelasi dengan penambahan konsentrasi Kalium pada daerah pembesaran. Bila tanaman kekurangan kalium maka pembesaran dan perpanjangan sel terhambat (Bel dan Rahmania, 2001).

\subsection{Tangkai Daun}

Tangkai daun merupakan bagian daun yang mendukung helainya dan bertugas untuk menempatkan helaian daun tadi pada posisi sedemikian rupa, hingga dapat memperoleh cahaya matahari yang sebanyak-banyaknya (Tjitrosoepomo, 2001). Pengaruh aplikasi pemberian bokashi cair terhadap jumlah tangkai daun lamtoro dapat dilihat pada Tabel 4.

Tabel 4. Jumlah Tangkai Daun (cm/56 hari).

\begin{tabular}{|c|c|c|c|c|c|}
\hline \multirow{2}{*}{ Dosis bokashi Cair } & \multicolumn{4}{|c|}{ Ulangan } & \multirow{2}{*}{ Rerata } \\
\hline & $\mathrm{I}$ & II & III & IV & \\
\hline Kontrol & 11,31 & 11,00 & 12,50 & 11,56 & $11,59^{\mathrm{b}}$ \\
\hline $50 \mathrm{ml} / 1$ liter air & 13,81 & 13,13 & 12,25 & 11,56 & $12,69^{\mathrm{ab}}$ \\
\hline $150 \mathrm{ml} / 1$ liter air & 13,75 & 13,81 & 12,88 & 13,25 & $13,42^{\mathrm{ab}}$ \\
\hline $250 \mathrm{ml} / 1$ liter air & 18,56 & 12,38 & 12,88 & 13,13 & $14,23^{\mathrm{a}}$ \\
\hline
\end{tabular}

Ket: Angka yang diikuti superscript yang sama menunjukkan berbeda tidak nyata $(P>0,05)$ pada $\alpha 0,05$

Hasil sidik ragam (anova) menunjukkan level bokashi cair tidak menunjukkan beda nyata antar perlakuan terhadap variabel pengamatan jumlah tangkai daun dimana tanaman lamtoro yang diberikan bokashi cair ( $250 \mathrm{ml} / 1$ liter air) cenderung meningkatkan jumlah tangkai daun $(23,75 \mathrm{~cm})$ dibandingkan tanaman lamtoro yang diberikan bokashi cair $50 \mathrm{ml} / 1$ liter air, $150 \mathrm{ml} / 1$ liter air dan tanpa pemberian bokashi cair.

Rataan nilai jumlah tangkai daun tanaman tertinggi adalah pada perlakuan $250 \mathrm{ml} / 1$ liter air (14,23 tangkai/56 hari) kemudian diikuti oleh perlakuan 150 $\mathrm{ml} / 1$ liter air (13,42 tangkai/56 hari) dikuti lagi oleh perlakuan $50 \mathrm{ml} / 1$ liter air (12,69 tangkai/56 hari) dan perlakuan kontrol (11,59 tangkai/56 hari). Hal ini diduga karena adanya kandungan unsur $\mathrm{N}$ pada perlakuan $250 \mathrm{ml} / 1$ liter air = $52,5 \%$, unsur P perlakuan $250 \mathrm{ml} / 1$ liter air $=1,0 \%$, dan Unsur K perlakuan 250 $\mathrm{ml} / 1$ liter air $=12,5 \%$ dapat memberikan hasil pertumbuhan per hari yang tertinggi pada tanaman perlakuan $250 \mathrm{ml} / 1$ liter air : 0,25 batang/hari), dapat dijelaskan bahwa dengan kandungan unsur hara tersebut, dapat memacu pertumbuhan tanaman lamtoro akan optimal yang dilihat dari tinggi tanaman Jika dibandingkan dengan penelitian Amri et al. (2013), menunjukkan bahwa pertumbuhan dan produksi tanaman jagung yang diberi perlakuan pupuk bokashi dengan takaran $180 \mathrm{~g} /$ tanaman memberikan hasil terbaik 0,21 helai/hari. Dalam penelitian ini sedikit lebih nyata yang diduga diakibatkan oleh kandungan unsur hara pupuk. Pupuk cair memiliki kandungan unsur hara tergolong tinggi yang didapat dari slurry, EM4 dan ekstrak Chromolaena odorata mampu meningkatkan pertumbuhan tanaman.

Banyaknya unsur hara $\mathrm{N}$ yang tersedia dapat meningkatkan kesuburan daun yang cepat berubah dengan menumbuhkan tunas baru dan tunas muda menjadi banyak dan lebar dengan warna yang lebih hijau dan dapat meningkatkan kadar protein dalam tubuh tanaman. Nitrogen yang dibutuhkan untuk membentuk senyawa penting seperti klorofil, asam nukleat, dan enzim sedangkan unsur hara mikro berfungsi terutama dalam pembentukan daun dan klorofil pada daun. Apabila pembentukan daun tersebut terganggu maka proses fotosintesis akan terganggu bilamana ada kekurangan nitrogen, tanaman akan tumbuh lambat dan kerdil (Novizan, 2002). 


\subsection{Bobot segar Tanaman.}

Bobot segar merupakan berat segar yang ditimbang setelah pasca panen. Selanjutnya hasil tersebut ditimbang sebagai data berat segar menggunakan timbangan digital. Pengaruh aplikasi pemberian bokashi cair terhadap bobot segar lamtoro yang dapat dilihat pada Tabel 5.

Tabel 5. Bobot Segar tanaman (gram)

\begin{tabular}{cccccc}
\hline \multirow{2}{*}{ Dosis bokashi cair } & \multicolumn{4}{c}{ Ulangan } & \multirow{2}{*}{ Rerata } \\
\cline { 2 - 4 } & I & II & III & IV & \\
\hline Kontrol & 17,77 & 8,56 & 23,65 & 3,45 & 13,36 \\
\hline $50 \mathrm{ml} / 1$ liter air & 18,49 & 14,23 & 24,40 & 4,09 & 15,30 \\
\hline $150 \mathrm{ml} / 1$ liter air & 19,19 & 26,74 & 29,33 & 5,84 & 20,27 \\
\hline $250 \mathrm{ml} / 1$ liter air & 19,82 & 34,95 & 33,68 & 6,55 & 23,75 \\
\hline
\end{tabular}

Hasil sidik ragam menunjukkan level bokashi cair tidak menunjukkan pengaruh nyata antar perlakuan terhadap variabel pengamatan berat segar tanaman. Rataan nilai pengukuran bobot segar tertinggi adalah pada perlakuan $250 \mathrm{ml} / 1$ liter air $(23,75 \mathrm{~g})$ kemudian diikuti oleh perlakuan $150 \mathrm{ml} / 1$ liter air $(20,27 \mathrm{~g})$ dikuti lagi oleh perlakuan $50 \mathrm{ml} / 1$ liter air $(13,3 \mathrm{~g})$ dan perlakuan kontrol (15,30 g). Hal ini diduga karena adanya kandungan unsur $\mathrm{N}$ pada perlakuan $250 \mathrm{ml} / 1$ liter air $=52,5 \%$, unsur P perlakuan $250 \mathrm{ml} / 1$ liter air $=1,0 \%$, dan Unsur $\mathrm{K}$ perlakuan $250 \mathrm{ml} / 1$ liter air $=12,5 \%$ dapat memberikan hasil pertumbuhan per hari yang tertinggi pada tanaman perlakuan $(250 \mathrm{ml} / 1$ liter air : 0,42 g/hari) dapat dijelaskan bahwa dengan unsur hara tersebut, memacu pertumbuhan tanaman lamtoro akan optimal yang dilihat dari bobot segar tanaman. Jika dibandingkan dengan penelitian Amiroh (2017), menunjukkan bahwa tanaman melon yang diberi perlakukan pupuk bokashi dengan takaran $1,93 \mathrm{~g} /$ pot memberikan hasil terbaik $0,04 \mathrm{~g} /$ hari. Dalam penelitian ini sedikit lebih nyata yang diduga diakibatkan oleh kandungan unsur hara pupuk. Pupuk cair memiliki kandungan unsur hara tergolong tinggi yang didapat dari slurry, EM4 dan ekstrak Chromolaena odorata mampu meningkatkan pertumbuhan tanaman (Tabel 1).

Menurut Nasir (2008), penggunaan pupuk bokashi berpengaruh terhadap peningkatan ketersediaan nutrisi tanaman, aktivitas hama dan penyakit/patogen dapat ditekan, Peningkatan aktivitas mikroorganisme indogenus yang menguntungkan, seperti Mycorhiza, Rhizobium, bakteri pelarut fosfat, Fiksasi Nitrogen, mengurangi kebutuhan pupuk dan pestisida kimia.

\subsection{Bobot kering Tanaman.}

Bobot kering merupakan berat kering pada tanaman yang dilakukan pengeringan dengan menggunakan oven selama 24 jam dengan tingkat suhu $105^{\circ} \mathrm{C}$ selanjutnya ditimbang berat kering dari tanaman. Pengaruh aplikasi pemberian bokashi cair terhadap bobot kering lamtoro yang dapat dilihat pada Tabel 6.

\section{Tabel 6. Bobot Kering Tanaman (gram)}

\begin{tabular}{|c|c|c|c|c|c|}
\hline \multirow{2}{*}{ Dosis bokashi cair } & \multicolumn{4}{|c|}{ Ulangan } & \multirow{2}{*}{ Rerata } \\
\hline & I & II & III & IV & \\
\hline Kontrol & 11,57 & 6,39 & 13,22 & 1,81 & $8,25^{\mathrm{a}}$ \\
\hline $50 \mathrm{ml} / 1$ liter air & 13,23 & 9,83 & 19,36 & 3,30 & $11,43^{\mathrm{a}}$ \\
\hline $150 \mathrm{ml} / 1$ liter air & 7,07 & 7,04 & 15,88 & 2,81 & $8,20^{\mathrm{a}}$ \\
\hline $250 \mathrm{ml} / 1$ liter air & 14,53 & 23,23 & 17,34 & 3,47 & $14,64^{\mathrm{a}}$ \\
\hline
\end{tabular}

Ket: Angka yang diikuti superscript yang sama menunjukkan berbeda tidak nyata $(P>0,05)$ pada $\alpha 0,05$.

Hasil sidik ragam (anova) menunjukkan level bokashi cair tidak menunjukkan pengaruh nyata antar perlakuan terhadap variabel pengamatan bobot kering tanaman dimana tanaman lamtoro yang diberikan bokashi cair $(250$ $\mathrm{ml} / 1$ liter air) cenderung memiliki berat kering tanaman terberat $(14,64)$ dibandingkan tanaman lamtoro yang diberikan bokashi cair $50 \mathrm{ml} / 1$ liter air, 150 $\mathrm{ml} / 1$ liter air dan tanpa pemberian bokashi cair.

Rataan nilai pengukuran bobot kering tertinggi adalah pada perlakuan 250 $\mathrm{ml} / 1$ liter air $(14,64 \mathrm{~g})$ kemudian diikuti oleh perlakuan $50 \mathrm{ml} / 1$ liter air $(11,43$ g) dikuti lagi oleh dan perlakuan kontrol $(8,25 \mathrm{~g})$ dan perlakuan $150 \mathrm{ml} / 1$ liter air $(8,20 \mathrm{~g})$. Hal ini diduga karena adanya kandungan unsur $\mathrm{N}$ pada perlakuan 250 $\mathrm{ml} / 1$ liter air $=52,5 \%$, unsur P perlakuan $250 \mathrm{ml} / 1$ liter air $=1,0 \%$, dan Unsur $\mathrm{K}$ perlakuan $250 \mathrm{ml} / 1$ liter air $=12,5 \%$ dapat memberikan hasil pertumbuhan per hari yang tertinggi pada tanaman perlakuan $(250 \mathrm{ml} / 1$ liter air : 0,26 g/hari) dapat dijelaskan bahwa dengan kandungan unsur hara tersebut, memacu pertumbuhan tanaman lamtoro akan optimal yang dilihat dari bobot kering. Jika dibandingkan dengan dengan penelitian Sadjadi et al. (2017), menunjukkan bahwa tanaman rumput raja yang diberi perlakuan pupuk bokashi kotoran sapi dengan takaran $150 \mathrm{~g} /$ polibag memberikan hasil terbaik $0,12 \mathrm{~g} /$ hari. Dalam penelitian ini sedikit lebih nyata yang diduga diakibatkan oleh kandungan unsur hara pupuk. Pupuk cair memiliki kandungan unsur hara tergolong tinggi yang didapat dari slurry, EM4 dan ekstrak Chromolaena odorata mampu meningkatkan pertumbuhan tanaman.

Penggunaan pupuk memiliki kandungan unsur hara yang ada dalam pupuk bokashi dapat memacu pertumbuhan tanaman seperti yang dinyatakan oleh Nasir (2008). Hal ini sejalan dengan pernyataan Wahyudi (2009), bahwa peningkatan bobot kering tanaman di kontrol oleh kemampuan tanah dalam menyuplai unsur $\mathrm{N}$ ke daerah rhizorver untuk di absorpsi oleh tanaman. Meningkatnya bahan organik berarti akan meningkatkan ketersediaan unsur-unsur tersebut bagi tanaman.

\section{Simpulan}

Dari hasil analisis dan pembahasan yang dilakukan maka dapat disimpulkan bahwa pemberian bokashi cair dengan level $(250 \mathrm{ml} / 1$ liter air) memberikan tinggi tanaman tertinggi, diameter batang terbesar, jumlah tangkai daun terbanyak, berat segar tanaman terberat dan berat kering tanaman terberat pada tanaman lamtoro (Leucaena leucocephala).

\section{Pustaka}

Amri, P.S., Mbue K.B. dan E. Harso K. 2013. Pemberian Pupuk Bokashi dan NPK Terhadap Pertumbuhan Produksi Tanaman Jagung Manis (Zea mais L.). Jurnal Online Agroekoteknologi, 1 (2): 37-44.

Amiroh, A. 2017. Pengaplikasian Dosis Pupuk Bokashi dan $\mathrm{KNO}_{3}$ Terhadap Pertumbuhan dan Hasil Tanaman Melon (Cucumis Melo.L). Jurnal Saintis, 9 (1): 25-36.

Bel dan Rahmania, 2001. Telaah Faktor Pembatas Kacang Tanah. penelitian palawija. http://docs.goegle.com. [diakses tanggal 01 November 2018].

Febriyanti., E. Purwati., Apriman. 2012. Pengaruh Penambahan Bahan Organik Dalam Pembuatan Pupuk Organik Padat Slurry Biogas Feses Sapi Perah Terhadap Kandungan N, P dan K. Jurnal Peternakan Indonesia, 12 (1): 270-278.

Gomez, K.A., dan Gomez, A.A. 2010. Prosedur Statistik Untuk Penelitian Pertanian. $\mathrm{Ed}^{2}$. UI Press: Jakarta

Hidayat, M.F. 2003. Pemanfaatan Asam Humat dan Omega pada Pemberian Pupuk NPK terhadap Pertumbuhan Gamelina arborea Roxb yang Diinokulasi Cendawan Mikroba Arbuskular (CMA). Tesis. Program Pascasarjana. Institut Pertanian Bogor.

Indriani, Y.H. 2004. Membuat Kompos Secara Kilat. Penebar Swadaya. Jakarta.

Kastono, D. 2005. Tanggapan Pertumbuhan dan Hasil Kedelai Hitam Terhadap Penggunaan Pupuk Organik dan Biopestisida Gulma Siam (Chromolaena odorata). Jurnal ilmu pertanian, 4 (1): 4-7.

Lingga. 2003. Petunjuk penggunaan pupuk. Penerbit Swadaya. Jakarta.

Marsela, T.D.A., Kaligus, dan D. Rustandi, M.B. Kaunang. 2017. Pengaruh pemberian bokashi kotoran ayam terhadap pertumbuhan lamtoro (Leucaena 1.). Jurnal zootek, 38 (1):44-49.

Nasir. 2008. Pengaruh penggunaan pupuk bokashi pada pertumbuhan dan produksi palawija dan sayuran. https://www.dispertanak.pandengglang. go.id. [diakses pada tanggal 20 Oktober 2018].

Nismawati. 2013. Pengaruh Pemberian Bokashi Terhadap Pertumbuhan Semai Kemiri. Jurnal Warta Rima, 1 (1):1-8.

Novizan. 2002. Petunjuk pemupukan yang efektif. Jakarta. Agro Media Pustaka.

Oman. 2003. Kandungan Nitrogen (N) Pupuk Organik Cair Dari Hasil Penambahan Urine Pada Limbah (Sludge) Keluaran Instalasi Gas Bio dengan Masukan Feses Sapi. Seminar Nasional Pangan. UPN "Veteran" Yogyakarta.

Prariesta, D dan Winata, R. 2009. Peningkatan Kualitas Pupuk Organik Cair Dari Limbah Cair Produksi Biogas. Tugas Akhir Jurusan Teknik Kimia. Institut Teknologi Sepuluh November. Surabaya.

Sadjadi, B. Herlina, dan W. Supendi. 2017. Level Penambahan Bokashi Kotoran Sapi Terhadap Pertumbuhan Dan Produksi Pada Panen Pertama Rumput Raja (P.purpureophoides). Jurnal sains peternakan Indonesia, 12 (4): 411 418.

Sutedjo, M. 2002. Pupuk dan cara pemupukan. Rineka Cipta. Jakarta.

Tisdale, S.L., W.L. Nelson, dan J.D. Beaton. 1985. Soil Fertility and Fertilizer. Mac Millan Publ. Co. Inc., New York. 754pp.

Tjitrosoepomo, G. 2001. Taksonomi Tumbuhan. Gajah Mada University Press. Yogyakarta.

Wahyudi, I. 2009. Manfaat bahan organik terhadap peningkatan ketersediaan fosfor dan penurunan toksisitas alumunium di ultisol. Disertasi. Universitas Brawijaya, Malang.

Yulipriyanto, H. 2010. Pengomposan Fase Thermofilik Limbah Organic Kotoran Ayam Pada Lingkungan Artificial Menggunakan Indore Heap Method. Prosiding seminar nasional hasil penelitian pertanian. 